\title{
Interaction and Mechanism between Imidazolium Ionic Liquids and the Zwitterionic Amino Acid Tyr: a DFT Study
}

\author{
Zhiwei Wu ${ }^{1,2}$, Weilu Ding ${ }^{1}$, Yaqin Zhang ${ }^{1}$, Yanlei Wang ${ }^{1}$, Hongyan $\mathrm{He}{ }^{1,3,{ }^{*}}$ \\ ${ }^{1}$ Beijing Key Laboratory of Ionic Liquids Clean Process, Institute of Process Engineering, Chinese Academy of Sciences, \\ Beijing 100190, China. \\ ${ }^{2}$ Sino-Danish College, University of Chinese Academy of Sciences, Beijing 100049, China. \\ ${ }^{3}$ Zhengzhou Institute of Emerging Industrial Technology, Zhengzhou 450000, China.
}

\begin{abstract}
Ionic liquids (ILs) are thermally and chemically stable and have adjustable structures, which gives them the potential to be used as green, efficient biomolecular solvents. Given the critical role of ILs in dissolving biomolecules, the mechanism of interaction between them deserves further study. Herein, density functional theory (DFT) calculations, using the SMD implicit water solvent model, were employed to study the interaction and mechanism between a hydrophobic zwitterionic amino acid (Tyr) and a series of imidazolium ILs with different alkyl chain lengths and methylation sites. The contributions of hydrogen bonding ( $\mathrm{H}$-bonding), electrostatic effects, induction, and dispersion to the intermolecular interactions were determined by combining the symmetry-

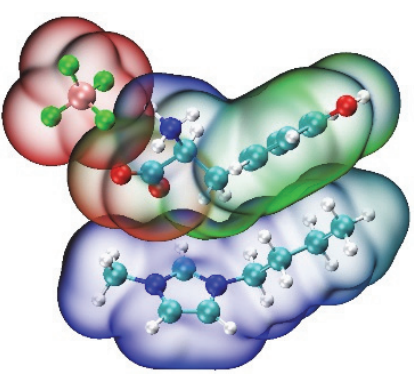
adapted perturbation theory (SAPT), the atoms in molecules (AIM) theory, and reduced density gradient (RDG) analysis. The results indicate that the $\mathrm{H}$-bonding between the IL cation and Tyr is stronger than that between the IL anion and Tyr; however, the binding between either ion and Tyr is dominated by electrostatic effects. By contrast, the difference between the induction and dispersion forces is small when methylation occurs on the C2 site of the imidazolium cation; whereas, it is significantly large when methylation takes place on the N3 site. This is rationalized by the interaction patterns that vary based on the methylation site. $\mathrm{H}$-bonding and $\Pi^{+}-\pi$ stacking interactions between the imidazole and benzene rings are dominant during $\mathrm{C} 2$-methylation, while $\mathrm{H}$-bonding and $\mathrm{C}_{\text {Alkyl }}-\mathrm{H} \cdots \pi$ interactions between the alkyl chain and benzene ring are dominant during N3-methylation. Increasing the side alkyl chain length has different effects on the interaction energy to cations with different methylation sites. During N3-methylation, when the side alkyl chain length increases from 4 to 12 , there are significant van der Waals interactions between the Tyr benzene and the side alkyl chain. However, these van der Waals interactions are inapparent when methylation takes place on the $\mathrm{C} 2$ site. Finally, the synergetic effect of the $\mathrm{H}$ bonding and the interaction between the benzene and the side alkyl chain for $\mathrm{C} 2$-methylation is greater than the $\mathrm{H}$-bonding and the interaction between the imidazole and benzene rings for N3-methylation, when the side alkyl chain length $n>9$. Therefore, the interaction strength and mechanism in these imidazolium-Tyr complexes can be regulated by changing the methylation site and the side alkyl chain length of the cation. Further study of ion-pair and Tyr reveals that the change tendency of the interaction energy of IL-Tyr systems is consistent with that of cation-Tyr cases, and the ion pair further stabilizes the binding with Tyr. These results illustrate the interaction mechanism of IL-Tyr systems and provide a novel strategy for the design and screening of functional ILs for amino acid extraction and separation in the future.
\end{abstract}

Key Words: Ionic liquids; Zwitterionic amino acid; Interaction and mechanism; Hydrogen bond effect; Van der Waals effect

\footnotetext{
Received: February 19, 2020; Revised: March 21, 2020; Accepted: April 6, 2020; Published online: April 10, 2020.

"Corresponding author. Email: hyhe@ipe.ac.cn; Tel.: +86-10-82544875.

This work was supported by the National Science Fund for Excellent Young Scholars, China (21922813), Key Program of National Natural Science Foundation of China (21834006), General program of National Natural Science Foundation of China (21978027), Key Research Program of Frontier Sciences of CAS (QYZDB-SSW-SLH022), and Youth Innovation Promotion Association of CAS (2017066).

国家自然科学基金优秀青年科学基金(21922813), 国家自然科学基金重点项目(21834006), 国家自然科学基金面上项目(21978027), 中国科学院前沿科 学重点研究计划(QYZDB-SSW-SLH022), 中国科学院青年创新促进会(2017066)资助项目

(C) Editorial office of Acta Physico-Chimica Sinica
} 


\title{
咪唑类离子液体与酪氨酸相互作用及机理的密度泛函理论研究
}

\author{
吴智伟 ${ }^{1,2}$, 丁伟璐 ${ }^{1}$, 张雅琴 ${ }^{1}$, 王艳磊 ${ }^{1}$, 何宏艳 ${ }^{1,3,}{ }^{*}$ \\ 1 中国科学院过程工程研究所离子液体清洁过程北京市重点实验室, 北京 100190 \\ 2 中国科学院大学中丹学院, 北京 100049 \\ 3 郑州中科新兴产业技术研究院，郑州 450000
}

\begin{abstract}
摘要: 离子液体的物理化学性质稳定且结构可调, 被认为是潜在的新一代绿色高效生物分子溶剂。本文通过密度泛函理 论研究了系列咪唑基离子液体与两性离子型氨基酸(酪氨酸)的相互作用及机理。利用对称微扰理论(SAPT)、分子中的原 子理论(AIM)及约化密度梯度函数(RDG), 分析了氢键作用、静电力、诱导力和色散力对离子液体-氨基酸体系相互作用 的贡献。计算结果表明静电作用对于阴、阳离子与酪氨酸的相互作用占主导地位。对于系列阳离子而言, 具有不同的甲 基取代位点和烷基侧链长度对不同的相互作用模式会产生显著影响。其中, 当甲基位于咪唑环的 $\mathrm{C} 2$ 位点时, 诱导力与色 散力占比差别较小; 当甲基取代位于咪唑环的N3位点时, 诱导力与色散力占比差别较大。产生这一差异的原因在于当甲 基位于 $\mathrm{C} 2$ 位时, 氢键、咪唑环与苯环之间的 $\pi^{+}-\pi$ 作用为主要作用模式, 而甲基取代位为 $\mathrm{N} 3$ 位时, 氢键和烷基链与苯环 之间的 $\mathrm{C}_{\text {Alkyl }}-\mathrm{H} \cdots \pi$ 作用则成为主导。进一步获得离子对-酪氨酸的相互作用能变化趋势与阳离子-酪氨酸的变化趋势一 致, 阴阳离子的共同作用使其与酪氨酸结合更稳定。该研究结果阐明了离子液体中阳离子氢键位点及侧链长度差异对于 离子液体-酪氨酸体系的相互作用模式的影响机制, 为高效分离氨基酸的功能性离子液体的设计和篮选提供了新思路。
\end{abstract}

关键词：离子液体；两性离子型氨基酸；相互作用机理；氢键作用；范德华相互作用 中图分类号: 0641

\section{Introduction}

Ionic liquids (ILs) are a kind of salts composed of organic cations and organic or inorganic anions, which features with low vapor pressure, excellent chemical stability, and thermal stability ${ }^{1-4}$. Most of ILs can exist stably in aqueous, acid and alkali environment, and the polarity of solution can be adjusted by tuning the combination of cations and anions to form two-phase or multi-phase separation medium ${ }^{5-7}$. These unique properties make ILs potential useful solvents for biomolecules ${ }^{8-10}$. For instance, in ILs, life primary biomolecules such as DNA, amino acid, and protein are found to have good solubility and stability. In particular, hydrophobic biomolecules are more prone to dissolve in the hydrophobic ILs-aqueous two-phase system, whereas difficult in traditional solvents ${ }^{11-13}$. Generally speaking, the hydrophobicity of ILs has a significant effect on the solubility of biomolecules, which has been illustrated by many studies ${ }^{14-16}$.

Also, it is found that the cations or anions of ILs with a localized positive or negative charge and the charged amino acid residues of protein molecules can produce evident electrostatic interaction during the protein dissolution process, especially the hydrogen bond (H-bond) widely exists, which plays a vital role in biomolecule solubility ${ }^{17-19}$. For example, the opening and closing status of Candida Antarctica lipase B (CALB) in ILs 1butyl-3-methylimidazolium chloride $([\mathrm{Bmim}][\mathrm{Cl}])$ and 1-butyl3-methylimidazolium trifluoromethylsulfonate ([Bmim][TFO]) are determined by the $\mathrm{H}$-bonds between amino acid residues and anions ${ }^{20,21}$. Besides, it has been proved that the large imidazole or pyridyl based cations display apparent van der Waals interactions with amino acids, where the long alkyl chain attached to the cation increases the hydrophobic interaction with biomolecules 22,23. In all, the solubility and stability of biomolecules in ILs largely depend on the interactions between ILs and biomolecules, in which electrostatic interaction, $\mathrm{H}$ bonds, van der Waals interaction, and steric effects contribute cooperatively ${ }^{24,25}$.

Given the critical role of ILs in dissolving and separating biomolecules, it is necessary to address the interaction mechanism deeply ${ }^{15}$. In this study, the intermolecular interactions between the zwitterion form of hydrophobic amino acid tyrosine (Tyr) and four ILs equipped by series of imidazolium cations which possess different alkyl chain length and methylation site $\left(\mathrm{C}_{4}-3 \mathrm{mim}, \mathrm{C}_{4}-2 \mathrm{mim}, \mathrm{C}_{12}-3 \mathrm{mim}, \mathrm{C}_{12}-2 \mathrm{mim}\right.$, see Fig. 1) combined with a hydrophobic tetrafluoroborate anion ${ }^{26}$
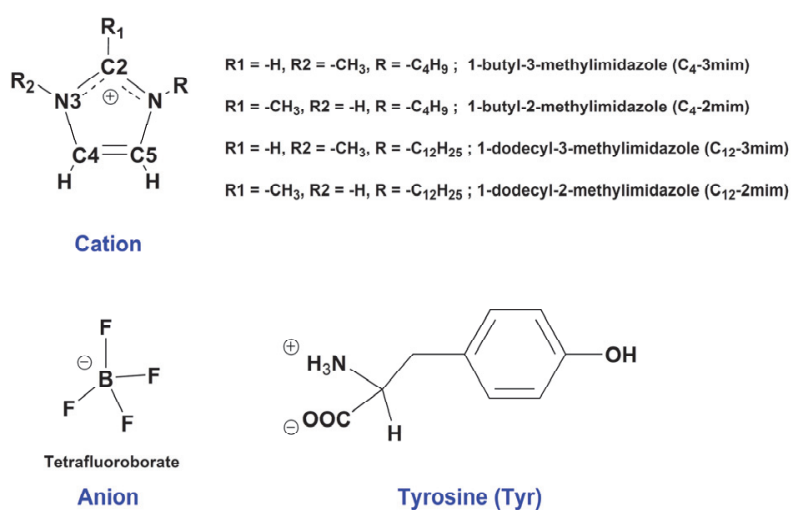

Fig. 1 The structures of studied cations and anion of ILs and amino acid Tyr. 
$\left(\mathrm{BF}_{4}\right)$ were studied by DFT calculations. The characterization of various interactions, i.e., H-bonding, induced, and electrostatic interaction, aims at providing how the methylation site and chain length of these considered cations govern the orientation of Tyr in water phase unambiguously. Understanding the effect of the varied chain length and methylation site of ILs on the ILs-amino acid interaction can help to screen and design efficient ILs for dissolving and separating specified biomolecule.

\section{Methodology}

\subsection{Computational details}

All DFT calculations were carried out by the Gaussian 09 D. 01 program ${ }^{27}$. For the optimization of isolated cation, anion, and Tyr, the density functional theory (DFT) B3LYP ${ }^{28}$ functional combined with $6-31+\mathrm{G}(d, p)$ basis set were used. As for ILs-Tyr complexes, B3LYP/6-31+G(d,p) and M06-2X $29 / 6-311+\mathrm{G}(d, p)$ level were used for the structure optimization and energy calculation, respectively. The subsequent calculation of frequencies at the same level based on the optimized geometries was performed to determine these geometries being indeed the minima on the potential energy surface. For a better evaluation of dispersion, Grimme's D3 dispersion correction ${ }^{30}$ was used in all simulation period. Notably, to obtain the reliable structures of cation/anion-Tyr and ILs-Tyr complexes, different inputs as the initial state were constructed, and the most stable one from the energy point was selected to perform the remaining analysis. Simultaneously, to reflect a more realistic environment of the complexes in water solvent, SMD implicit solvent model ${ }^{31}$, which treats the solution as a continuously polarizable media was used by the structure optimization and energy calculation in Gaussian 09 program ${ }^{32}$. Further identification of the contribution of electrostatic, exchange, induction, and dispersion items to the total intermolecular interaction energy was analyzed by the symmetry adapted perturbation theory ${ }^{33}$ (SAPT), which was performed in SAPT0/6-311+G $(d, p)$ level as implemented in PSI4 program ${ }^{34}$. Moreover, the visual analysis of the interaction energy by atoms in molecules (AIM) theory ${ }^{35}$ and the reduced density gradient (RDG) ${ }^{36}$ were completed via Multiwfn code ${ }^{37}$.

\subsection{Theoretical background}

The intermolecular interaction energy was calculated by the following equation:

$$
\Delta E_{\text {Ion-Tyr }}=2625.5 \times\left(E_{\text {Ion-Tyr }}-E_{\text {Ion }}-E_{\text {Tyr }}\right)
$$

where $E_{\mathrm{Ion}-\mathrm{Tyr}}$ (in $\mathrm{kJ} \cdot \mathrm{mol}^{-1}$ ) is the total energy of cation/anion-Tyr complexes, $E_{\mathrm{Ion}}$ is the energy of cation or anion, and $E_{\mathrm{Tyr}}$ is the energy of Tyr unit in a.u., respectively.

To distinguish the sensitive dependence of many-body effects on complexes binding and accompanying intermolecular interactions, the energy decomposition analysis by SAPT, which gives the contributions from electrostatic, exchange, induction, and dispersion terms to overall binding energy is an efficient tool to quantitative each component ${ }^{38}$. The electrostatic term $\left(E_{\mathrm{Elst}}\right)$ reflects the electrostatic interaction between molecules, the exchange term $\left(E_{\text {Exch }}\right)$ represents the exchange-repulsion effect, the induction term $\left(E_{\text {Ind }}\right)$ comprises the polarization of a monomer under the other polar molecule as well as the charge transfer between molecules, and the dispersion term $\left(E_{\mathrm{Dis}}\right)$ mirrors the interaction of instantaneous dipoles between nonpolar molecules through the motion of electrons 39,40 . Accordingly, these four terms can be divided into the attractive forces ( $\left.E_{\mathrm{Elst}}, E_{\text {Ind }}, E_{\mathrm{Dis}}\right)$ and repulsive force $\left(E_{\mathrm{Exch}}\right)$. To provide an intuitive understanding of the proportion of each attractive term to the $\Delta E_{\text {Ion-Tyr, the contribution percentage for each attractive }}$ term can be calculated by the following equation:

$$
E_{x} \%=\left(E_{x} /\left(E_{\text {Elst }}+E_{\text {Ind }}+E_{\text {Dis }}\right)\right) \times 100 \%
$$

where $E_{\mathrm{X}}$ represents any one of the attractive components $\left(E_{\mathrm{Elst}}\right.$, $E_{\text {Ind, }}$ and $\left.E_{\text {Dis }}\right)$.

To identify the strength of the H-bond in its donor-acceptor, the AIM theory ${ }^{41,42}$ can be used to analyze the bonding characteristics qualitatively. There are a set of criteria for the electron density $\left(\rho_{\mathrm{BCP}}\right)$, and Laplacian of the electron density $\left(\nabla^{2} \rho_{\mathrm{BCP}}\right)$ proposed at bond critical points (BCPs) for the conventional $\mathrm{H}$-bonds ${ }^{43,44}$. Both parameters for the closed-shell interactions as H-bonds are positive within the ranges of 0.002 0.035 a.u. for the $\rho_{\mathrm{BCP}}$ and $0.024-0.139$ a.u. for the $\nabla^{2} \rho_{\mathrm{BC}}$. Meanwhile, the Laplacian of electron density at BCPs has positive values indicating that why the nature of these $\mathrm{H}$-bonds is noncovalent. And the negative values of potential energy density $\left(H_{\mathrm{BCP}}\right)$ at $\mathrm{BCPs}$ imply that these H-bonds have the characteristic of covalent bonds, and the positive values of potential energy density $\left(H_{\mathrm{BCP}}\right)$ indicate these $\mathrm{H}$-bonds have electrostatic properties.

\section{Results and discussion}

As mentioned above, the ILs are consisted of $\mathrm{BF}_{4}$ anion combined with the imidazole cations feature with the different side alkyl chain and methylation site. Therefore, to emphasize the impacts of the side alkyl chain length and methylation site of the cations on the orientation of Tyr in considered ILs-Tyr complexes, the different conformers of isolated cation, anion, and Tyr are optimized to obtain the most stable one in the lowest energy. Then the selected conformer of each species was used to construct the ion-Tyr complexes and do the initial analysis of energy decomposition, AIM, and RDG. Before the discussion, it is noted that the critical atom of each species needs to be defined for clarity: for cation, the $-\mathrm{CH}_{3}$ is substituted on the $\mathrm{C} 2$ or N3 site of imidazole ring and the side alkyl chain is substituted on the $\mathrm{N} 1$ site, so the $\mathrm{H}$ atoms on the $\mathrm{C} 2, \mathrm{~N} 3$, and side alkyl chain are labeled as $\mathrm{C} 2-\mathrm{H}, \mathrm{N} 3-\mathrm{H}$, and $\mathrm{C}_{\text {Alkyl }}-\mathrm{H}$; for anion, the $\mathrm{F}$ atoms are labeled as F1, F2, F3, and F4; as for Tyr amino acid, the $\mathrm{N}$ atom is defined as $\mathrm{N}_{\mathrm{Tyr}}$, the $\mathrm{O}$ atoms of $-\mathrm{COO}^{-}$and $-\mathrm{OH}$ are defined as $\mathrm{O}_{\mathrm{COO}}$ and $\mathrm{O}_{\mathrm{OH}}$, and the $\mathrm{H}$ atoms of Tyr benzene ring and Tyr amino are labeled as $\mathrm{C}_{\mathrm{Ben}}-\mathrm{H}$ and $\mathrm{C}_{\mathrm{Amino}}-\mathrm{H}$, respectively (see Fig. 1).

\subsection{ESP and NPA charge analysis}

For the aim of predicting the most plausible binding sites aroused by electrophilic and nucleophilic between ion and Tyr 


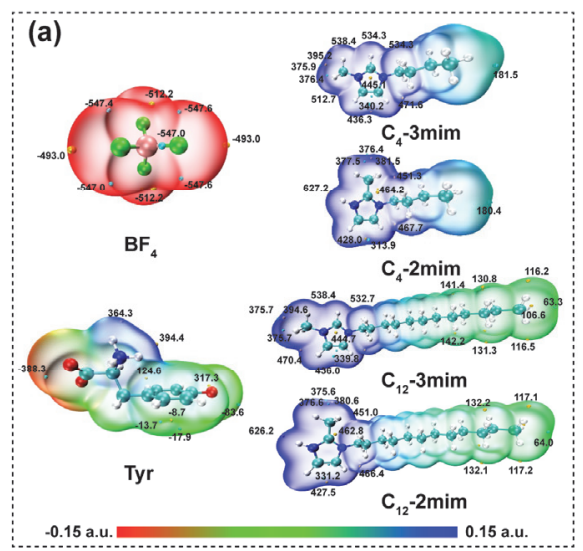

(b)

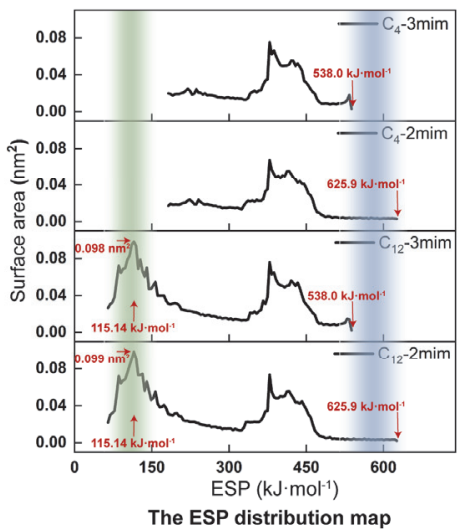

Fig. 2 The electrostatic potential of anion, Tyr and cations (a) and the electrostatic potential distributions of cations (b).

The van der Waals ESP of each species are mapped under 0.001 a.u. electron density equivalent surface and the unit of the ESP label in Fig. $2 \mathrm{a}$ is kJ·mol ${ }^{-1}$. The positive

electrostatic potential is colored by blue, and the negative electrostatic potential is colored by red, while the green represents the neutral electrostatic potential area. Color online.

complexes, the intuitively surface electrostatic potential (ESP) distributions of cations/anion, and Tyr are firstly investigated. For cation and anion, the most positive region (the blue) generally concentrates on the imidazole ring of each cation, and the most negative region (the red) centers on the $\mathrm{BF}_{4}$ anion (Fig. 2a). As for Tyr, the $-\mathrm{NH}_{3}{ }^{+}$group displays positive electrostatic potential, and the $-\mathrm{COO}^{-}$group shows negative electrostatic potential, which is in accordance with the property of zwitterion and supports the accumulation of ILs on the charged protein surface. Meanwhile, an apparent decrease of electrostatic potential from 625.9 to $538.0 \mathrm{~kJ} \cdot \mathrm{mol}^{-1}$ can be observed when the $-\mathrm{CH}_{3}$ alters from $\mathrm{C} 2$ to $\mathrm{N} 3$ position (the second and the first panels in Fig. 2b), which significantly reduces the ability of electrophilicity no matter what the side alkyl chain length is. On the other hand, with the extension of the side alkyl chain length, the molecular volume is increased, which is evidenced by the increased surface area with a low electrostatic potential between $70-180 \mathrm{~kJ} \cdot \mathrm{mol}^{-1}$ (the green shadow labeled in Fig. 2b). Although it has little effect on the high electrostatic surface area distribution of the imidazole ring, a stronger van der Waals potential is still anticipated.

To further reflect the strength of the electrophilicity of critical $\mathrm{H}$ atom on the imidazole ring (labeled as $\mathrm{X}-\mathrm{H}$ ) quantitatively, the natural population analysis (NPA) is characterized. From Table 1 , the variation of the charge of identical $\mathrm{X}-\mathrm{H}$ in series of cations can be neglected. Meanwhile, the charge of N3-H is almost 2-folds larger than that of $\mathrm{C} 2-\mathrm{H}(0.478$ vs. 0.271$)$, and the charges of $\mathrm{C} 4-\mathrm{H}$ and $\mathrm{C} 5-\mathrm{H}(0.266-0.267)$ are subtly smaller than that of $\mathrm{C} 2-\mathrm{H}$. The electrophilicity of the $\mathrm{H}$ atom of $\mathrm{N} 3-\mathrm{H}$ bond is stronger than that of the $\mathrm{C} 2-\mathrm{H}$ bond. Notably, the charge distribution of $\mathrm{CH}_{3}-\mathrm{H}_{\text {of }} \mathrm{C}_{4}-3 \mathrm{mim}$ and $\mathrm{C}_{12}$ 3 mim cations significantly reduces by $\sim 51 \%$ compared to that of $\mathrm{N} 3-\mathrm{H}$ of $\mathrm{C}_{4}-2 \mathrm{mim}$ and $\mathrm{C}_{12}-2 \mathrm{mim}$ cations, while the distribution of $\mathrm{CH}_{3}-\mathrm{H}$ of $\mathrm{C}_{4}-2 \mathrm{mim}$ and $\mathrm{C}_{12}-2 \mathrm{mim}$ produces only $\sim 4 \%$ decrease with respect to the quantity of $\mathrm{C}_{2}-\mathrm{H}$ in $\mathrm{C}_{4}-3 \mathrm{mim}$ and $\mathrm{C}_{12}-3 \mathrm{mim}$. This significant difference is mainly caused by the varied atom type of $\mathrm{C}$ and $\mathrm{N}$ of $\mathrm{H}$ attached. The substitution of
$-\mathrm{CH}_{3}$ on the $\mathrm{N} 3$ site alters the $\mathrm{N}-\mathrm{H}$ into $\mathrm{C}-\mathrm{H}$. Therefore, the distinct electronic properties of $\mathrm{C}$ and $\mathrm{N}$ atoms lead to a noticeable decrease in NPA charge of $\mathrm{H}$ atom. However, the bond type remains $\mathrm{C}-\mathrm{H}$ bond when the $-\mathrm{CH}_{3}$ is substituted on the $\mathrm{C} 2$ site; thus, the inapparent charge decrease of $\mathrm{H}$ atom is observed. These above indicate that regulating the methylation site and side alkyl chain length can affect the electrostatic and van der Waals effect potentially. Through the ESP and NPA analysis, the plausible site of electrophilic for cation and nucleophilic of anion to Tyr can be preliminarily determined. And the construction of cations/anion-Tyr complexes will consider the plausible site.

\subsection{The characterization of interaction energy of ion-Tyr complexes}

\subsubsection{The $\mathrm{H}$-bond and interaction energy}

Based on the most stable conformer of the isolated ion and Tyr, as well as the plausible site of electrophilic or nucleophilic, the cation-Tyr and anion-Tyr complexes have been constructed. For each complex, several initial configurations are taken into consideration and subjected to the structural relaxation, and the lowest one in total energy is screened out for the analysis of the intermolecular interaction. The most stable conformers have been shown in Fig. 3, and others with their H-bonds properties have been shown in Figs. S1-S3 and Table. S1 (in Supporting Information).

Table 1 The charge distribution of critical $\mathrm{H}$ atom on the imidazole ring in each cation by natural population analysis.

\begin{tabular}{ccccc}
\hline $\mathrm{R}-\mathrm{H}$ & $\mathrm{C}_{4}-3 \mathrm{mim}$ & $\mathrm{C}_{4}-2 \mathrm{mim}$ & $\mathrm{C}_{12}-3 \mathrm{mim}$ & $\mathrm{C}_{12}-2 \mathrm{mim}$ \\
\hline$-\mathrm{C} 2-\mathrm{H}$ & 0.271 & $\mathrm{~N} / \mathrm{A}$ & 0.271 & $\mathrm{~N} / \mathrm{A}$ \\
$-\mathrm{N} 3-\mathrm{H}$ & $\mathrm{N} / \mathrm{A}$ & 0.478 & $\mathrm{~N} / \mathrm{A}$ & 0.478 \\
$-\mathrm{C} 4-\mathrm{H}$ & 0.267 & 0.267 & 0.266 & 0.267 \\
$-\mathrm{C} 5-\mathrm{H}$ & 0.267 & 0.266 & 0.267 & 0.266 \\
$-\mathrm{CH}_{3}-\mathrm{H} 1$ & 0.230 & 0.258 & 0.230 & 0.257 \\
$-\mathrm{CH}_{3}-\mathrm{H} 2$ & 0.232 & 0.260 & 0.232 & 0.259 \\
$-\mathrm{CH}_{3}-\mathrm{H} 3$ & 0.235 & 0.257 & 0.235 & 0.257 \\
\hline & & Unit in a.u.
\end{tabular}




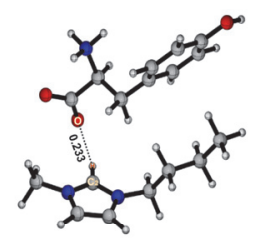

$-44.96 \mathrm{~kJ} \cdot \mathrm{mol}^{-1}$ (a) $\mathrm{C}_{4}-3 \mathrm{mim}-\mathrm{Tyr}$

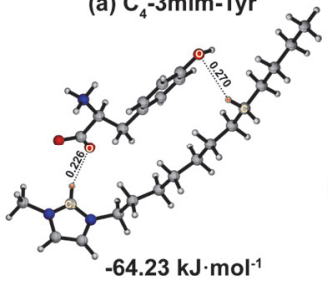

(c) $\mathrm{C}_{12}-3 \mathrm{mim}-\mathrm{Tyr}$

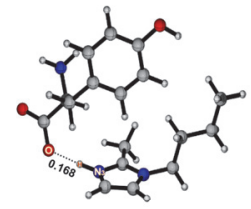

$-57.31 \mathrm{~kJ} \cdot \mathrm{mol}^{-1}$ (b) $\mathrm{C}_{4}-2 \mathrm{mim}-\mathrm{Tyr}$

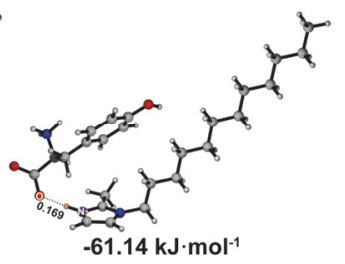

(d) $\mathrm{C}_{12}-2 \mathrm{mim}-\mathrm{Tyr}$

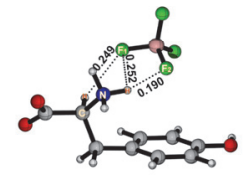

$-31.75 \mathrm{~kJ} \cdot \mathrm{mol}^{-1}$

(e) $\mathrm{BF}_{4}-\mathrm{Tyr}$

Fig. 3 The most stable conformer and intermolecular interaction energy for cations-Tyr (a-d) and anion-Tyr complexes (e).

The dashed line is the H-bond formed between ion and Tyr, and the unit of the distances of $\mathrm{H}$-bond is $\mathrm{nm}$.

Clearly, the benzene ring of Tyr tends to stay around the imidazole ring of $\mathrm{C}_{4}-2 \mathrm{mim}$ and $\mathrm{C}_{12}-2 \mathrm{mim}$, whereas it orientates toward the side alkyl chain when the $-\mathrm{CH}_{3}$ of $\mathrm{C}_{4}-2$ mim and $\mathrm{C}_{12}$ 2 mim alters to the $\mathrm{N} 3$ site. For the situation of the $-\mathrm{CH}_{3}$ on the $\mathrm{C} 2$ site, the $\mathrm{N} 3-\mathrm{H}$ of cation forms the $\mathrm{H}$-bond with the $-\mathrm{COO}^{-}$ of Tyr where the distances of $\mathrm{N} 3-\mathrm{H} \cdots \mathrm{O}_{\text {coo }}$ is $\sim 0.169 \mathrm{~nm}$ (see Table 2). After the $-\mathrm{CH}_{3}$ alters to the $\mathrm{N} 3$ site, the distances of $\mathrm{H}$-bond, which formed between the $\mathrm{C} 2-\mathrm{H}$ and $-\mathrm{COO}^{-}$is prolonged by $\sim 0.06 \mathrm{~nm}$ significantly. It implies that the change of methylation can determine the strength of $\mathrm{H}$-bond of cationTyr complexes because the $\mathrm{H}$-bond involving $\mathrm{N} 3-\mathrm{H}$ is stronger than that of $\mathrm{C} 2-\mathrm{H}$. On the other hand, the change of the methylation site determines the orientation of Tyr. The methylation on the $\mathrm{N} 3$ site makes the stronger $\mathrm{N}-\mathrm{H}$ H-bond donor change into the weaker $\mathrm{C}-\mathrm{H} \mathrm{H}$-bond donor, resulting in a similar strengthen of $\mathrm{C}_{\mathrm{Alkyl}}-\mathrm{H}$ compared to $\mathrm{C} 2-\mathrm{H}$. As a

Table 2 The distances and angles of $\mathrm{H}$-bond in the cation-Tyr and anion-Tyr complexes, as well as the related intermolecular interaction energy.

\begin{tabular}{lcccc}
\hline \multicolumn{1}{c}{ Complex } & $\mathrm{H}-$ bond & Distance $/ \mathrm{nm}$ & Angle $/\left({ }^{\circ}\right)$ & $\Delta E_{\text {Ion-Tyr }} /\left(\mathrm{kJ} \cdot \mathrm{mol}^{-1}\right)$ \\
\hline $\mathrm{C}_{4}-3 \mathrm{mim}-\mathrm{Tyr}$ & $\mathrm{C} 2-\mathrm{H} \cdots \mathrm{O}_{\mathrm{COO}}$ & 0.233 & 155.0 & -44.96 \\
$\mathrm{C}_{4}-2 \mathrm{mim}-\mathrm{Tyr}$ & $\mathrm{N} 3-\mathrm{H} \cdots \mathrm{O}_{\mathrm{COO}}$ & 0.168 & 174.7 & -57.31 \\
$\mathrm{C}_{12}-3$ mim-Tyr & $\mathrm{C} 2-\mathrm{H} \cdots \mathrm{O}_{\mathrm{COO}}$ & 0.226 & 151.3 & -64.23 \\
& $\mathrm{C}_{\mathrm{Alkyl}}-\mathrm{H} \cdots \mathrm{O}_{\mathrm{OH}}$ & 0.270 & 132.7 & $\mathrm{~N} / \mathrm{A}$ \\
$\mathrm{C}_{12}-2 \mathrm{mim}-\mathrm{Tyr}$ & $\mathrm{N} 3-\mathrm{H} \cdots \mathrm{O}_{\mathrm{COO}}$ & 0.169 & 168.9 & -61.14 \\
$\mathrm{BF}_{4}-\mathrm{Tyr}$ & $\mathrm{N}_{\mathrm{Tyr}}-\mathrm{H} \cdots \mathrm{F} 1$ & 0.252 & 106.9 & -31.75 \\
& $\mathrm{~N}_{\mathrm{Tyr}}-\mathrm{H} \cdots \mathrm{F} 2$ & 0.190 & 161.8 & $\mathrm{~N} / \mathrm{A}$ \\
& $\mathrm{C}_{\mathrm{Amino}}-\mathrm{H} \cdots \mathrm{F} 1$ & 0.249 & 124.6 & $\mathrm{~N} / \mathrm{A}$ \\
\hline
\end{tabular}

result, Tyr tends to interact with cation by $\mathrm{C} 2-\mathrm{H} \cdots$ Ocoo $\mathrm{H}-$ bond and van der Waals effect between benzene ring of Tyr and side alkyl chain of cation collaboratively. As for $\mathrm{BF}_{4}-\mathrm{Tyr}$, there are two kinds of $\mathrm{F} \cdots \mathrm{H}$ H-bonds detected, one is the $\mathrm{N}_{\mathrm{Tyr}}-\mathrm{H} \cdots$ $\mathrm{F}$, and another is the $\mathrm{C}_{\mathrm{Amino}}-\mathrm{H} \cdots \mathrm{F}$. Overall, the distances of $\mathrm{H}-$ bonds in $\mathrm{BF}_{4}-\mathrm{Tyr}$ are longer than that in series of cation-Tyr additives, and the angles of $\mathrm{H}$-bonds range from $106^{\circ}-160^{\circ}$, suggesting that the strength of H-bond in anion-Tyr is weaker than that of cation-Tyr systems.

Apart from the $\mathrm{H}$-bond, the intermolecular interaction energy ( $\Delta E_{\text {Ion-Tyr }}$ ) of these ion-Tyr complexes further supports the dependence of the stable binding on the methylation site and side alkyl chain qualitatively. For the cations feature with shorter side alkyl chain ( $\mathrm{C}_{4}-2 \mathrm{mim}$ and $\left.\mathrm{C}_{4}-3 \mathrm{mim}\right)$, the $\Delta E_{\text {Ion-Tyr }}$ are -57.31 and $-44.96 \mathrm{~kJ} \cdot \mathrm{mol}^{-1}$, which are smaller than the values of longer side alkyl chain constructed $\mathrm{C}_{12}-2 \mathrm{mim}$ and $\mathrm{C}_{12}-3 \mathrm{mim}(-61.14$ and $\left.-64.23 \mathrm{~kJ} \cdot \mathrm{mol}^{-1}\right)$. The $\Delta E_{\text {Ion-Tyr }}$ of $\mathrm{C}_{4}-2 \mathrm{mim}$-Tyr is obviously stabilized by $12.35 \mathrm{~kJ} \cdot \mathrm{mol}^{-1}$ than that of $\mathrm{C}_{4}-3 \mathrm{mim}-\mathrm{Tyr}$ and the difference in $\Delta E_{\text {Ion-Tyr }}$ of two long side alkyl chain based cationTyr cases is only $3.09 \mathrm{~kJ} \cdot \mathrm{mol}^{-1}$. It is worth noting that with the increase of side alkyl chain length, the two systems show an opposite trend of interaction energy, which is $\mathrm{C}_{4}-2 \mathrm{mim}-\mathrm{Tyr}<$ $\mathrm{C}_{4}-3$ mim-Tyr, whereas $\mathrm{C}_{12}$-2mim-Tyr $>\mathrm{C}_{12}$-3mim-Tyr. For better understanding, the cations with different side alkyl chain $(n=4-12)$ are considered for further calculation. All stable structures have been shown in Figs. S4-S5 (in Supporting information). Fig. 4 shows the interaction energy of different cations with Tyr, and a turning point is observed as the chain length is $n=10$. In the $\mathrm{C}_{n}$-2mim cations with shorter side alkyl chain $(n<9)$, H-bond interaction is more pronounced, and the strong $\mathrm{N} 3-\mathrm{H} \cdots \mathrm{O}$ H-bond leads to a more significant interaction than $\mathrm{C}_{\mathrm{n}}-3 \mathrm{mim}-\mathrm{Tyr}(n<9)$. On the contrary, when $\mathrm{n}$ is larger than 10, the van der Waals interaction between the benzene ring and long alkyl chain in $\mathrm{C}_{n}-3$ mim-Tyr complexes is more significant. It can be speculated that the synergistic effect of the $\mathrm{C} 2-\mathrm{H} \cdots \mathrm{O}$ $\mathrm{H}$-bond and benzene ring-alkyl chain interaction in $\mathrm{C}_{n}$ - $3 \mathrm{mim}$ Tyr systems finally overwhelms the $\mathrm{N} 3-\mathrm{H} \cdots \mathrm{O} \mathrm{H}-$ bond and benzene ring-imidazole ring interaction in $\mathrm{C}_{n}$-2mim-Tyr systems. On the other hand, the $\Delta E_{\text {Ion-Tyr }}$ of $\mathrm{BF}_{4}$-Tyr $(-31.75$ $\mathrm{kJ} \cdot \mathrm{mol}^{-1}$ ) shows that the anion-Tyr is less stable compared to cation-Tyr systems, suggesting that the binding of Tyr is more

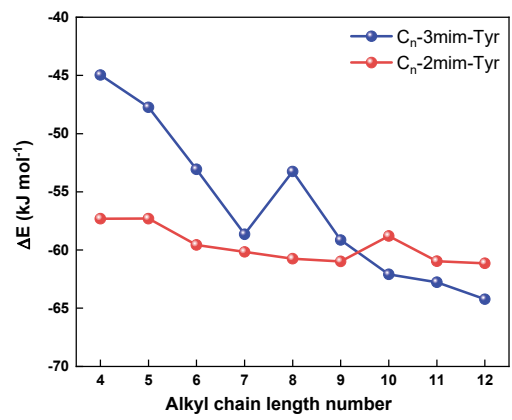

Fig. 4 The interaction energy of cation-Tyr complexes with alkyl chain length growth. 
liable to cation. This can also be expected, as the cation-neutral interaction is usually advantageous due to the spread out of charge, while for anion-neutral, there could be unfavorable closed-shell repulsion.

\subsubsection{Energy decomposition analysis}

After analyzing the interaction energy of ion-Tyr complexes, we will turn the concentration to the proportions from the different attractive components to the $\Delta E_{\text {Ion-Tyr, containing }}$ electrostatic $\left(E_{\text {Elst }}\right)$, induction $\left(E_{\text {Ind }}\right)$ and dispersion $\left(E_{\text {Dis }}\right)$ terms as depicted in the theoretical background. The contributions of these attractive components in each ion-Tyr case are illustrated in the form of a histogram in Fig. 5.

For a series of cation-Tyr systems, the dominant factor to the binding comes from the $E_{\text {Elst }}$ term that it contributes by one half to the total interaction energy in each case. However, the percentage of the $E_{\text {Dis }}$ and $E_{\text {Ind }}$ terms shows a different change tendency from case to case. For $-\mathrm{CH}_{3}$ substituted on the N3 site, the $E_{\text {Dis }}$ is more obvious than that on the $\mathrm{C} 2$ site, which is mainly attributed to the fact that the $\mathrm{C} 2-\mathrm{H} \cdots \mathrm{C}_{\mathrm{COO}} \mathrm{H}$-bond makes Tyr shifting to the side alkyl chain of cation, subsequently induces the $\mathrm{C}_{\mathrm{Alkyl}}-\mathrm{H} \cdots \pi$ interaction ${ }^{45}$ between the side alkyl chain and non-polar benzene ring of Tyr. Oppositely, the $E_{\text {Ind }}$ is overweight than the $E_{\text {Dis }}$ when the $-\mathrm{CH}_{3}$ locates on the $\mathrm{C} 2$ site, and the main reason is that the $\mathrm{N} 3-\mathrm{H} \cdots \mathrm{C}_{\mathrm{COO}} \mathrm{H}$-bond attracts Tyr keeping away from the side alkyl chain, consequently produces the $\pi^{+}-\pi$ interaction ${ }^{46}$ between the polar imidazole ring and non-polar benzene ring. It is worth noting that the difference between $E_{\text {Dis }}$ and $E_{\text {Ind }}$ in $\mathrm{C}_{4}-2 \mathrm{mim}$-Tyr and $\mathrm{C}_{12}-2 \mathrm{mim}-\mathrm{Tyr}$ is smaller than that in $\mathrm{C}_{4}-3 \mathrm{mim}-\mathrm{Tyr}$ and $\mathrm{C}_{12}-3 \mathrm{mim}-\mathrm{Tyr}$, accounting that extending the side alkyl chain of the cation is less effective in the formation of the $\mathrm{C}_{\mathrm{Alkyl}}-\mathrm{H} \cdots \pi$ interaction when $-\mathrm{CH}_{3}$ situates on the $\mathrm{C} 2$ site of cation; therefore, the H-bonding effect dominates the whole interaction.

Differently, in $\mathrm{C}_{4}-3 \mathrm{mim}-\mathrm{Tyr}$ and $\mathrm{C}_{12}-3 \mathrm{mim}-\mathrm{Tyr}$, the $\mathrm{C} 2-\mathrm{H} \cdots$ Ocoo H-bond makes Tyr oriented to the side alkyl chain of cation, consequently produces the $\mathrm{C}_{\text {Alkyl }}-\mathrm{H} \cdots \pi$ interaction as the extending of the side alkyl chain. Therefore,

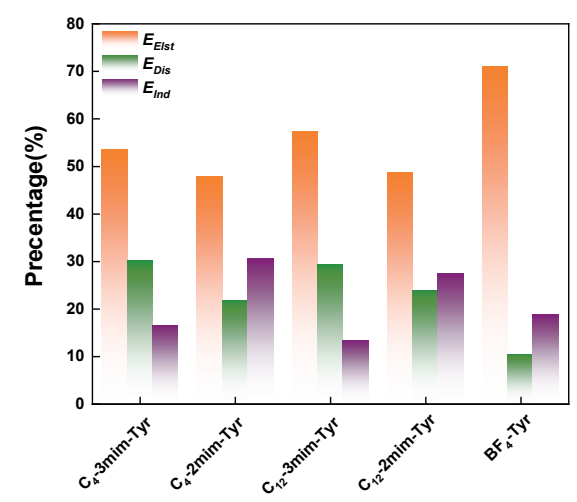

Fig. 5 The contribution percentage of the SAPT-derived constructive components of cation-Tyr and anion-Tyr systems. The orange, the green, and the purple stand for electrostatic, dispersion, and induction terms, respectively. Color online. the electrostatic and van der Waals effect collaborate to the binding of cation and Tyr. As for $\mathrm{BF}_{4}-\mathrm{Tyr}$ complexes, it can be found that the $E_{\text {Elst }}$ is overwhelmingly larger than the $E_{\text {Dis }}$ and

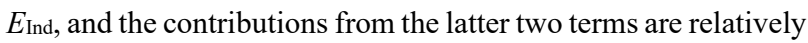
lower in less than $10 \%$ and $20 \%$. At the same time, the $E_{\text {Elst }}$ of anion-Tyr is significantly larger by $\sim 20 \%$ than that of cation-Tyr cases, illustrating why the electrostatic effect nearly governs the binding of $\mathrm{BF}_{4}$ and Tyr completely, while the van der Waals effect participates more in combining of cation and Tyr.

\subsubsection{AIM analysis}

Although $\mathrm{H}$-bond distance and angle can speculate the $\mathrm{H}$ bond strength qualitatively, the more details associated with the electron density of $\mathrm{H}$-bond are still not obtained. According to the AIM theory, the electron density $\left(\rho_{\mathrm{BCP}}\right)$, Laplacian of the electron density $\left(\nabla^{2} \rho_{\mathrm{BCP}}\right)$ and the potential energy density $\left(H_{\mathrm{BCP}}\right)$ can be used to illustrate the strength and nature of $\mathrm{H}$-bond at the bond critical points (BCPs) qualitatively. The H-bond and ionic bond are identified by $\nabla^{2} \rho_{\mathrm{BCP}}>0$ in the closed-shell interactions, while the covalent bond is characterized by $\nabla^{2} \rho_{\mathrm{BCP}}<0$; the extremely strong H-bond can also have negative Laplacian value; and the positive value of $\mathrm{H}_{\mathrm{BCP}}$ indicates the H-bond has electrostatic properties, separately.

The magnitudes of $\rho_{\mathrm{BCP}}, \nabla^{2} \rho_{\mathrm{BCP}}$, and $H_{\mathrm{BCP}}$ of all considered ion-Tyr complexes have been summarized in Table 3. Totally, the $\rho_{\mathrm{BCP}}$ and $\nabla^{2} \rho_{\mathrm{BCP}}$ of most H-bonds in considered complexes fall in the relative proposed ranges $\left(0.002-0.035\right.$ a.u. for the $\rho_{\mathrm{BCP}}$ and $0.024-0.139$ a.u. for the $\left.\nabla^{2} \rho_{\mathrm{BCP}}\right)$ where the former ranges in $0.007-0.047$ a.u. and the latter ranges in $0.021-0.138$ a.u. in our study, respectively. For the H-bond of the series of cation-Tyr complexes, the strength of H-bond decreases by order of $\mathrm{C}_{4}$ $2 \mathrm{mim}-\mathrm{Tyr}(0.047$ a.u. $) \approx \mathrm{C}_{12}-2 \mathrm{mim}-\mathrm{Tyr}(0.045$ a.u. $)>\mathrm{C}_{12}-3 \mathrm{mim}-$ Tyr (0.014 and 0.007 a.u.) $>\mathrm{C}_{4}-3 \mathrm{mim}-\mathrm{Tyr}$ (0.011 a.u.), respectively. It is worth noting that $-\mathrm{CH}_{3}$ substituted on the $\mathrm{C} 2$ site of imidazole ring induces more strengthened H-bond (N3-H $\cdots$ OCOO) with the largest $\rho_{\mathrm{BCP}}$ and $\nabla^{2} \rho_{\mathrm{BCP}}$ by 0.047 a.u. and 0.137 a.u. separately with respect to the situation of on the $\mathrm{N} 3$ site (the $\nabla^{2} \rho_{\mathrm{BCP}}$ is 0.039 and 0.047 a.u. for $\mathrm{C}_{4}-3 \mathrm{mim}-\mathrm{Tyr}$ and $\mathrm{C}_{12}$-3mim-Tyr). Simultaneously, $-\mathrm{CH}_{3}$ located on the $\mathrm{C} 2$ site produces a negative value of $H_{\mathrm{BCP}}\left(-5.634 \times 10^{-3}\right.$ and $-4.675 \times$ $10^{-3}$ a.u.), indicating that methylation on this site features a

Table 3 The electron density ( $\left.\rho_{\mathrm{BCP}}\right)$ and the associated value of Laplacian $\left(\nabla^{2} \rho_{\mathrm{BCP}}\right)$, as well as the potential energy density $\left(\mathrm{H}_{\mathrm{BCP}}\right)$ at the bond critical point in cation-Tyr and anion-Tyr complexes.

\begin{tabular}{clccc}
\hline Ion-Tyr & H-bond & $\rho_{\mathrm{BCP}} /$ (a.u.) & $\nabla^{2} \rho_{\mathrm{BCP}} /$ (a.u.) & $H_{\mathrm{BCP}} /\left(10^{-3}\right.$ a.u. $)$ \\
\hline $\mathrm{C}_{4}-3 \mathrm{mim}-\mathrm{Tyr}$ & $\mathrm{C} 2-\mathrm{H} \cdots \mathrm{O}_{\mathrm{COO}}$ & 0.011 & 0.039 & 1.437 \\
$\mathrm{C}_{4}-2 \mathrm{mim}-\mathrm{Tyr}$ & $\mathrm{N} 3-\mathrm{H} \cdots \mathrm{O}_{\mathrm{COO}}$ & 0.047 & 0.137 & -5.634 \\
$\mathrm{C}_{12}-3 \mathrm{mim}-\mathrm{Tyr}$ & $\mathrm{C} 2-\mathrm{H} \cdots \mathrm{O}_{\mathrm{COO}}$ & 0.014 & 0.047 & 1.626 \\
& $\mathrm{C}_{\mathrm{Alky}}-\mathrm{H} \cdots \mathrm{O}_{\mathrm{OH}}$ & 0.007 & 0.021 & 0.491 \\
$\mathrm{C}_{12}-2 \mathrm{mim}-\mathrm{Tyr}$ & $\mathrm{N} 3-\mathrm{H} \cdots \mathrm{O}_{\mathrm{COO}}$ & 0.045 & 0.138 & -4.675 \\
$\mathrm{BF}_{4}-\mathrm{Tyr}$ & $\mathrm{N}_{\mathrm{Tyr}}-\mathrm{H} \cdots \mathrm{F} 1$ & $\mathrm{~N} / \mathrm{A}$ & $\mathrm{N} / \mathrm{A}$ & $\mathrm{N} / \mathrm{A}$ \\
& $\mathrm{N}_{\mathrm{Tyr}}-\mathrm{H} \cdots \mathrm{F} 2$ & 0.023 & 0.098 & 2.025 \\
& $\mathrm{C}_{\mathrm{Amino}}-\mathrm{H} \cdots \mathrm{F} 1$ & 0.008 & 0.031 & 1.049 \\
\hline
\end{tabular}


strong electrostatic effect compared to that on the N3 site. These above mentioned again confirm that methylation on the $\mathrm{C} 2$ site is more favorable than that on the $\mathrm{N} 3$ site in the formation of stronger $\mathrm{H}$-bond and further stabilization of the binding. As for $\mathrm{BF}_{4}$-Tyr system, the strong $\mathrm{N}_{\mathrm{Tyr}}-\mathrm{H} \cdots \mathrm{F} 2$ (0.023 a.u.) and weak $\mathrm{C}_{\text {Amino }}-\mathrm{H} \cdots \mathrm{F} 1$ (0.008 a.u.) can be detected, while the electron density at $\mathrm{N}_{\mathrm{Tyr}}-\mathrm{H} \cdots \mathrm{F} 1$ is undetectable which is mainly aroused from the relatively longer $\mathrm{H}$-bond distance $(0.252 \mathrm{~nm})$ and smaller $\mathrm{H}$-bond angle $\left(106.9^{\circ}\right)$ compared to others.

In all, the methylation site change between the $\mathrm{C} 2$ and $\mathrm{N} 3$ site on the imidazole ring determines the $\mathrm{C} 2-\mathrm{H} \cdots \mathrm{O}_{\mathrm{COO}}$ and $\mathrm{N} 3-\mathrm{H} \cdots \mathrm{O}_{\mathrm{COO}} \mathrm{H}$-bond strength of cation-Tyr systems because the $\mathrm{N} 3-\mathrm{H}$ donor manifests stronger than the $\mathrm{C} 2-\mathrm{H}$ donor. Compared to the distinct influence of varying the methylation site on the strength of H-bond, the impact of extending side alkyl chain is faint. Oppositely, the H-bond strength in $\mathrm{BF}_{4}-\mathrm{Tyr}$ complexes is moderate with respect to that in $\mathrm{C}_{4}-2 \mathrm{mim}$-Tyr and $\mathrm{C}_{12}$-2mim-Tyr, suggesting the critical role of appropriate methylation site of the imidazole-based cation in interacting with Tyr preferentially.

\subsubsection{RDG analysis}

Apart from the useful tool of AIM to identify the nature of noncovalent, reduced density gradient (RDG) analysis is another powerful tool to explore noncovalent interaction intuitively. This method can provide more conspicuous information compared to AIM analysis in a deep comprehension of the varied interaction mechanism to noncovalent interaction. RDG $v s$. the electron density multiplied by the sign of second Hessian eigenvalue $\left(\operatorname{sign}\left(\lambda_{2}\right) \rho\right)$ is plotted by scatter graph (see the left panel in Fig. 6a-e) where the more negative value represents stronger electrostatic/H-bonding interaction (the blue), the positive value represents steric effect (the red), and the region close to zero represents van der Waals effect (the green), respectively.

In the series of cation-Tyr complexes, the location of the blue spikes in $\mathrm{C}_{4}-2 \mathrm{mim}$-Tyr and $\mathrm{C}_{12}-2 \mathrm{mim}$-Tyr falls into the more negative region (maximum to -0.047 a.u.) compared to $\mathrm{C}_{4}$ 3 mim-Tyr and $\mathrm{C}_{12}-3 \mathrm{mim}-\mathrm{Tyr}$ (maximum to -0.014 a.u.). Moreover, the corresponding region color of the disc-shaped blocks (the labeled circle in the right panel in Fig. 6a-e) for the $\mathrm{N} 3-\mathrm{H} \cdots$ Ocoo in $\mathrm{C}_{4}-2 \mathrm{mim}-\mathrm{Tyr}$ and $\mathrm{C}_{12}-2 \mathrm{mim}-\mathrm{Tyr}$ is dark blue in contrast to the green for the $\mathrm{C} 2-\mathrm{H}^{\cdots} \mathrm{O}_{\mathrm{COO}}$ in $\mathrm{C}_{4}-3$ mim-Tyr and $\mathrm{C}_{12}-3 \mathrm{mim}-\mathrm{Tyr}$. It is noted that in $\mathrm{C}_{4}-2 \mathrm{mim}-\mathrm{Tyr}$ and $\mathrm{C}_{12}$ $2 \mathrm{mim}-\mathrm{Tyr}$, the van der Waals interaction is observed between the benzene ring of Tyr and the imidazole ring of cation, while it is subtle between the benzene ring and the side alkyl chain, assuring that extending the side alkyl chain of cation produces little effect on the binding when methylation situates on the $\mathrm{C} 2$ site. Conversely, for $\mathrm{C}_{4}-3 \mathrm{mim}-\mathrm{Tyr}$ and $\mathrm{C}_{12}-3 \mathrm{mim}-\mathrm{Tyr}$, the benzene ring orientates to the side alkyl chain due to the formation of $\mathrm{C} 2-\mathrm{H} \cdots$ OCOo thus increases the $\mathrm{C}_{\mathrm{Alkyl}}-\mathrm{H}^{\cdots} \cdots \pi$ interaction. These combined directly imply that both of $\mathrm{C}_{4}$ 2mim-Tyr and $\mathrm{C}_{12}-2 \mathrm{mim}$-Tyr display a stronger H-bonding effect and $\pi^{+}-\pi$ interaction compared to $\mathrm{C}_{4}-3 \mathrm{mim}$-Tyr and $\mathrm{C}_{12}$ -

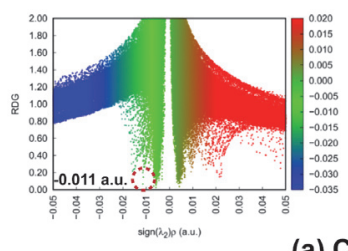

(a) $\mathrm{C}_{4}-3 \mathrm{mim}-\mathrm{Tyr}$
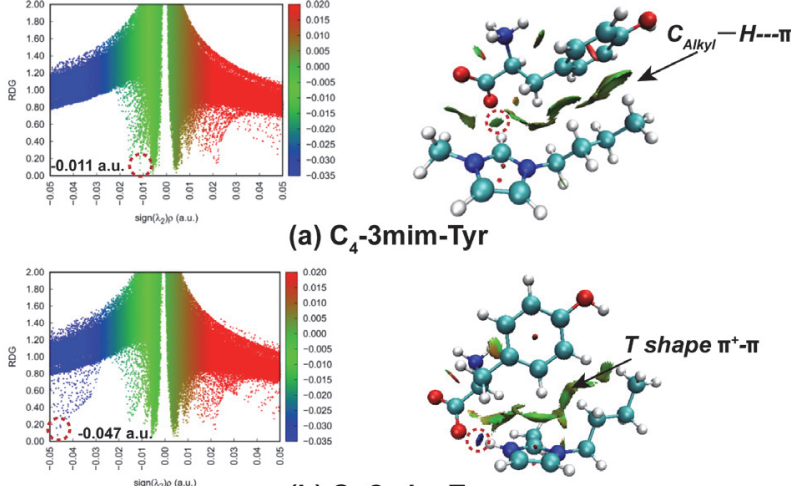

(b) $\mathrm{C}_{4}$-2mim-Tyr

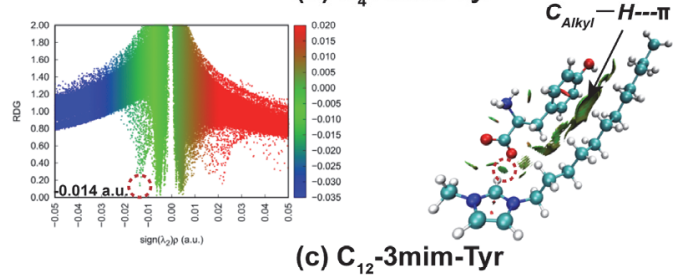

(c) $\mathrm{C}_{12}-3 \mathrm{mim}-\mathrm{Tyr}$

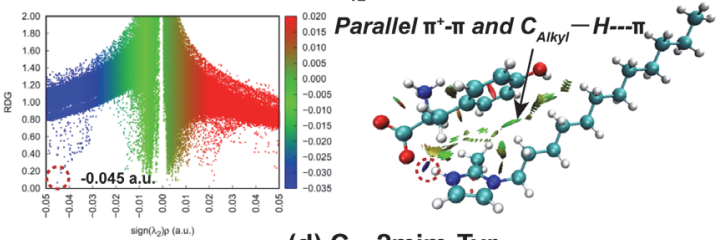

(d) $\mathrm{C}_{12}-2 \mathrm{mim}-\mathrm{Tyr}$
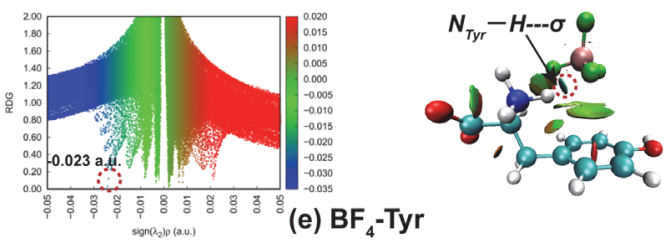

Fig. 6 The RDG scatter plot and surface plot of each cation-Tyr and anion-Tyr complexes (a-e).

The isovalue of scatter plots and surface plots is 0.5 a.u., the blue regions and green regions in the right of the corresponding $3 \mathrm{D}$ plots represent a strong electrostatic

interaction and a more dispersion attractive interaction, respectively. Color online.

3mim-Tyr which manifests a weaker H-bonding effect and $\mathrm{C}_{\text {Alkyl }}-\mathrm{H} \cdots \pi$ interaction, assuring that extending the side alkyl chain induces little effect on the van der Waal interaction between the benzene ring of Tyr and side alkyl chain of cation when methylation situates on the $\mathrm{C} 2$ site, whereas boosts the significant van der Waals interaction when methylation locates on the $\mathrm{N} 3$ site, separately. As for $\mathrm{BF}_{4}-\mathrm{Tyr}$ complexes, the location of the blue spikes falls into the more positive region ( -0.023 a.u.) with respect to that of $\mathrm{C}_{4}-2 \mathrm{mim}-\mathrm{Tyr}$ and $\mathrm{C}_{12}-2 \mathrm{mim}$ Tyr complexes. And the corresponding region color of the discshaped blocks for $\mathrm{N}_{\mathrm{Tyr}}-\mathrm{H} \cdots \mathrm{F}$ H-bond is green, suggesting an obvious $\mathrm{N}_{\mathrm{Tyr}}-\mathrm{H} \cdots \sigma$ interaction between the benzene ring and $\mathrm{BF}_{4}$ on the other hand. These above reflect that $\mathrm{C}_{4}-2 \mathrm{mim}$ and $\mathrm{C}_{12}$-2mim can interact with Tyr more easily, follows by the $\mathrm{BF}_{4}$ anion as well as $\mathrm{C}_{4}-3 \mathrm{mim}$ and $\mathrm{C}_{12}-3 \mathrm{mim}$. It is good in line with the H-bond distances and the AIM analysis, and considering the strong H-bonding effect among the $\mathrm{C}_{4}-2 \mathrm{mim}-\mathrm{Tyr}, \mathrm{C}_{12}-2 \mathrm{mim}-$ Tyr, and $\mathrm{BF}_{4}-\mathrm{Tyr}$, it can be anticipated that their combinations, 


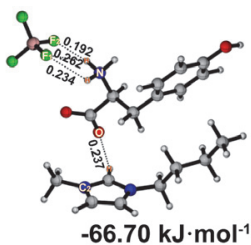

(a) $\left[\mathrm{C}_{4}-3 \mathrm{mim}\right]\left[\mathrm{BF}_{4}\right]-\mathrm{Tyr}$

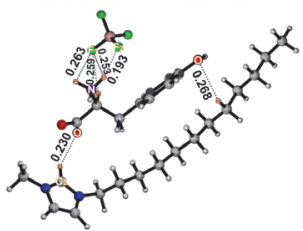

$-95.61 \mathrm{~kJ} \cdot \mathrm{mol}^{-1}$

(c) $\left[\mathrm{C}_{12}-3 \mathrm{mim}\right]\left[\mathrm{BF}_{4}\right]-\mathrm{Tyr}$

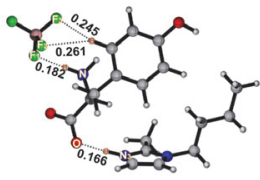

$-81.90 \mathrm{~kJ} \cdot \mathrm{mol}^{-1}$

(b) $\left[\mathrm{C}_{4}-2 \mathrm{mim}\right]\left[\mathrm{BF}_{4}\right]-\mathrm{Tyr}$

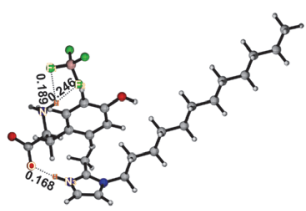

$-88.73 \mathrm{~kJ} \cdot \mathrm{mol}^{-1}$

(d) $\left[\mathrm{C}_{12}-2 \mathrm{mim}\right]\left[\mathrm{BF}_{4}\right]-\mathrm{Tyr}$
Fig. 7 The optimized conformers and intermolecular interaction energy for IL-Tyr complexes.

The unit of the $\mathrm{H}$-bond distances labeled in the picture is $\mathrm{nm}$.

namely $\left[\mathrm{C}_{4}-2 \mathrm{mim}\right]\left[\mathrm{BF}_{4}\right]$ and $\left[\mathrm{C}_{12}-2 \mathrm{mim}\right]\left[\mathrm{BF}_{4}\right]$, binding to Tyr can behave an excellent performance in extracting and separating Tyr.

\subsection{The interaction of IL and Tyr}

Because cation and anion appear in the form of ion pair in the real ILs which behaves more complicated structure, therefore, to obtain the interaction and mechanism between ILs and Tyr more appropriately, it is necessary to explore the structural behavior of ILs-Tyr complexes which is essential to reveal the extracting and separating mechanism. Based on the considered cations and anion, four kinds of ILs are constructed, namely [C $\mathrm{C}_{4}$ $2 \mathrm{mim}]\left[\mathrm{BF}_{4}\right], \quad\left[\mathrm{C}_{4}-3 \mathrm{mim}\right]\left[\mathrm{BF}_{4}\right], \quad\left[\mathrm{C}_{12}-2 \mathrm{mim}\right]\left[\mathrm{BF}_{4}\right]$, and $\left[\mathrm{C}_{12}-\right.$ $3 \mathrm{mim}]\left[\mathrm{BF}_{4}\right]$, respectively. The varied initial conformations and H-bonds properties of each IL-Tyr complexes have been shown in Fig. S6 and Table S2 (in Supporting Information), and the optimized most stable one has been shown in Fig. 7.
The evaluation of the interaction between IL and Tyr is calculated by the following equation ${ }^{47}$ :

$$
\Delta E_{\mathrm{IL}-\mathrm{Tyr}}=2625.5 \times\left(E_{\mathrm{IL}-\mathrm{Tyr}}-E_{\mathrm{IL}}-E_{\mathrm{Tyr}}\right)
$$

where the $E_{\mathrm{IL}-\mathrm{Tyr}}\left(\right.$ in $\left.\mathrm{kJ} \cdot \mathrm{mol}^{-1}\right)$ is the energy of IL-Tyr complexes, $E_{\mathrm{IL}}$ and $E_{\mathrm{Tyr}}$ are the energies of isolated IL and Tyr calculated on the structure of IL-Tyr complexes, respectively. As seen from Fig. 7, zwitterion Tyr has an electron-withdrawing group $-\mathrm{COO}^{-}$and an electron-donating group $-\mathrm{NH}_{3}{ }^{+}$, which acts as a bridge for connection of cation and anion. All kinds of ion can interact with Tyr via $\mathrm{H}$-bond where anion locates around the $-\mathrm{NH}_{3}^{+}$, and cation situates toward the $-\mathrm{COO}^{-}$. The orientation of cation and anion in each stable IL-Tyr complex is similar to that in the standalone ion-Tyr complexes.

The $\Delta E_{\mathrm{IL}-\mathrm{Tyr}}$ of IL-Tyr is more stabilized than that of the single cation-Tyr or anion-Tyr system that it decreases from $\left[\mathrm{C}_{12}\right.$ $3 \mathrm{mim}]\left[\mathrm{BF}_{4}\right]\left(-95.61 \mathrm{~kJ} \cdot \mathrm{mol}^{-1}\right)>\left[\mathrm{C}_{12}-2 \mathrm{mim}\right]\left[\mathrm{BF}_{4}\right](-88.73$ $\left.\mathrm{kJ} \cdot \mathrm{mol}^{-1}\right)>\left[\mathrm{C}_{4}-2 \mathrm{mim}\right]\left[\mathrm{BF}_{4}\right]\left(-81.90 \mathrm{~kJ} \cdot \mathrm{mol}^{-1}\right)>\left[\mathrm{C}_{4}-\right.$ $3 \mathrm{mim}]\left[\mathrm{BF}_{4}\right] \quad\left(-66.70 \mathrm{~kJ} \cdot \mathrm{mol}^{-1}\right)$, respectively. This is in accordance with the change tendency of $\Delta E_{\text {Ion-Tyr }}$ of cation-Tyr complexes listed in Table 2, suggesting that introducing anion to the cation-Tyr system does not break the binding between cation and Tyr. To further identify the difference of interaction mechanism between ion-Tyr and IL-Tyr complexes, the varied contributions from H-bond and van der Waal effect are analyzed in Table 4 and Fig. 8. From Table 4, it can be found that the strength of $\mathrm{H}$-bond in $\left[\mathrm{C}_{4}-2 \mathrm{mim}\right]\left[\mathrm{BF}_{4}\right]-\mathrm{Tyr}$ and $\left[\mathrm{C}_{12}-\right.$ $2 \mathrm{mim}]\left[\mathrm{BF}_{4}\right]-\mathrm{Tyr}$ is stronger than that of $\left[\mathrm{C}_{4}-3 \mathrm{mim}\right]\left[\mathrm{BF}_{4}\right]-\mathrm{Tyr}$ and $\left[\mathrm{C}_{12}-3 \mathrm{mim}\right]\left[\mathrm{BF}_{4}\right]-\mathrm{Tyr}$ that the $\rho \mathrm{BCP}$ ranges from $0.007-0.050$ a.u. for the former two and 0.011-0.022 a.u. for the latter two. Meanwhile, the value of $H_{\mathrm{BCP}}$ in $\left[\mathrm{C}_{4}-2 \mathrm{mim}\right]\left[\mathrm{BF}_{4}\right]-\mathrm{Tyr}(-7.241 \times$ $10^{-3}-1.922 \times 10^{-3}$ a.u. $)$ and $\left[\mathrm{C}_{12}-2 \mathrm{mim}\right]\left[\mathrm{BF}_{4}\right]-\mathrm{Tyr}(-5.678 \times$ $10^{-3}-1.959 \times 10^{-3}$ a.u.) is more negative compared to that in $\left[\mathrm{C}_{4}-3 \mathrm{mim}\right]\left[\mathrm{BF}_{4}\right]-\mathrm{Tyr}\left(1.300 \times 10^{-3}-2.007 \times 10^{-3}\right.$ a.u. $)$ and $\left[\mathrm{C}_{12}-\right.$

Table 4 The electron density $\left(\rho_{\mathrm{BCP}}\right)$ and the associated value of Laplacian $\left(\nabla^{2} \rho_{\mathrm{BCP}}\right)$, as well as the potential energy density $\left(H_{\mathrm{BCP}}\right)$ at the bond critical point in ILs-Tyr complexes.

\begin{tabular}{|c|c|c|c|c|}
\hline ILs-Tyr & H-bond & $\rho_{\mathrm{BCP}} /$ (a.u.) & $\nabla^{2} \rho_{\mathrm{BCP}} /$ (a.u.) & $H_{\mathrm{BCP}} /\left(10^{-3}\right.$ a.u. $)$ \\
\hline \multirow[t]{4}{*}[\mathrm{C}_{4}-3\mathrm{mim}]{$\left[\mathrm{BF}_{4}\right]-\mathrm{Ty}$} & $\mathrm{C} 2-\mathrm{H} \cdots \mathrm{O}_{\mathrm{COO}}$ & 0.011 & 0.035 & 1.300 \\
\hline & $\mathrm{N}_{\mathrm{Tyr}}-\mathrm{H} \cdots \mathrm{F} 1$ & 0.011 & 0.045 & 1.462 \\
\hline & $\mathrm{N}_{\mathrm{Tyr}}-\mathrm{H} \cdots \mathrm{F} 1$ & $\mathrm{~N} / \mathrm{A}$ & N/A & N/A \\
\hline & $\mathrm{N}_{\mathrm{Tyr}}-\mathrm{H} \cdots \mathrm{F} 2$ & 0.022 & 0.093 & 2.007 \\
\hline \multirow[t]{4}{*}[\mathrm{C}_{4}-2\mathrm{mim}]{$\left[\mathrm{BF}_{4}\right]-\mathrm{Tyr}$} & $\mathrm{N} 3-\mathrm{H} \cdots \mathrm{O}_{\mathrm{COO}}$ & 0.050 & 0.141 & -7.241 \\
\hline & $\mathrm{N}_{\mathrm{Tyr}}-\mathrm{H} \cdots \mathrm{F} 1$ & 0.027 & 0.115 & 1.922 \\
\hline & $\mathrm{C}_{\mathrm{Ben}}-\mathrm{H} \cdots \mathrm{F} 2$ & 0.006 & 0.022 & 0.867 \\
\hline & $\mathrm{C}_{\mathrm{Ben}}-\mathrm{H} \cdots \mathrm{F} 3$ & 0.008 & 0.030 & 0.995 \\
\hline \multirow[t]{6}{*}[\mathrm{C}_{12}-3\mathrm{mim}]{$\left[\mathrm{BF}_{4}\right]-\mathrm{Tyr}$} & $\mathrm{C} 2-\mathrm{H}^{\cdots}$ Ocoo & 0.007 & 0.023 & 0.556 \\
\hline & $\mathrm{C}_{\mathrm{Alkyl}}-\mathrm{H}^{\cdots} \mathrm{O}_{\mathrm{OH}}$ & 0.013 & 0.043 & 1.455 \\
\hline & $\mathrm{N}_{\mathrm{Tyr}}-\mathrm{H} \cdots \mathrm{F} 2$ & 0.022 & 0.091 & 2.022 \\
\hline & $\mathrm{N}_{\mathrm{Tyr}}-\mathrm{H} \cdots \mathrm{F} 1$ & $\mathrm{~N} / \mathrm{A}$ & $\mathrm{N} / \mathrm{A}$ & N/A \\
\hline & $\mathrm{N}_{\mathrm{Tyr}}-\mathrm{H} \cdots \mathrm{F} 1$ & $\mathrm{~N} / \mathrm{A}$ & N/A & N/A \\
\hline & $\mathrm{C}_{\mathrm{Ben}}-\mathrm{H} \cdots \mathrm{F} 1$ & 0.007 & 0.028 & 1.015 \\
\hline \multirow[t]{3}{*}[\mathrm{C}_{12}-2\mathrm{mim}]{$\left[\mathrm{BF}_{4}\right]-\mathrm{Tyr}$} & $\mathrm{N} 3-\mathrm{H} \cdots \mathrm{O}_{\mathrm{COO}}$ & 0.047 & 0.137 & -5.678 \\
\hline & $\mathrm{N}_{\mathrm{Tyr}}-\mathrm{H} \cdots \mathrm{F} 1$ & 0.024 & 0.100 & 1.959 \\
\hline & $\mathrm{N}_{\mathrm{Tyr}}-\mathrm{H} \cdots \mathrm{F} 2$ & $\mathrm{~N} / \mathrm{A}$ & N/A & N/A \\
\hline
\end{tabular}



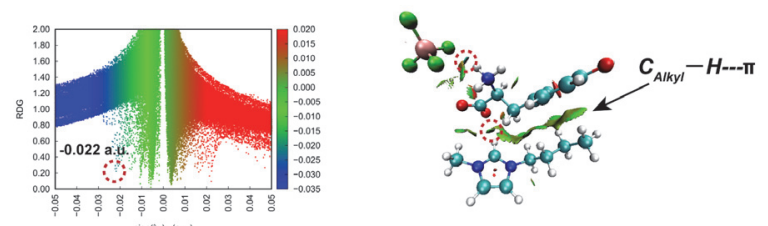

(a) $\left[\mathrm{C}_{4}-3 \mathrm{mim}\right]\left[\mathrm{BF}_{4}\right]-\mathrm{Tyr}$

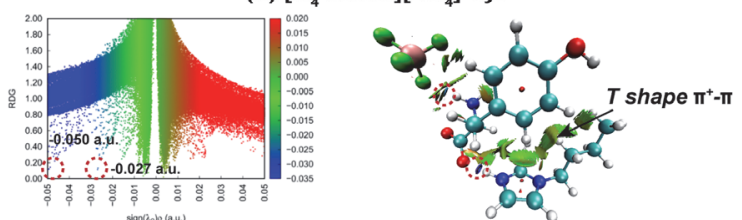

(b) $\left[\mathrm{C}_{4}-2 \mathrm{mim}\right]\left[\mathrm{BF}_{4}\right]-\mathrm{Tyr}$

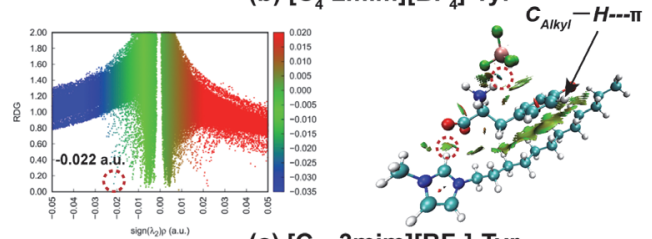

(c) $\left[\mathrm{C}_{12}-3 \mathrm{mim}\right]\left[\mathrm{BF}_{4}\right]-\mathrm{Tyr}$

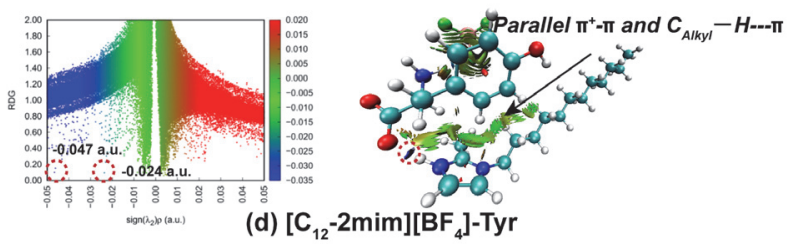

Fig. 8 RDG scatter plot and surface plot of each IL-Tyr complexes. The isovalue of scatter plots and surface plots is 0.5 a.u., the blue regions and green regions in the right of the corresponding $3 \mathrm{D}$ plots represent a strong electrostatic interaction and a more dispersion attractive interaction, respectively. Color online.

$3 \mathrm{mim}]\left[\mathrm{BF}_{4}\right]-\mathrm{Tyr}\left(0.556 \times 10^{-3}-2.022 \times 10^{-3}\right.$ a.u. $)$, implying the $\mathrm{H}$-bond in the latter two systems possess more obvious electrostatic effect.

As a whole, H-bond, electrostatic, and van der Waals effects have been observed in these IL-Tyr systems; their synergistic effects help to stabilize the binding between IL and Tyr. This insight accounts for the different extents of our considered ILs in extracting and separating Tyr amino acid. We believe that this can provide a novel strategy in design functional ILs in extracting and separating zwitterion amino acid in the future.

\section{Conclusions}

In summary, the intermolecular interaction and mechanism between a series of [cation] $\left[\mathrm{BF}_{4}\right]$ ILs and zwitterion amino acid Tyr have been investigated by DFT calculations in this work. For the series of the cation $\left(\mathrm{C}_{4}-2 \mathrm{mim}, \mathrm{C}_{4}-3 \mathrm{mim}, \mathrm{C}_{12}-2 \mathrm{mim}\right.$, and $\mathrm{C}_{12}$ $3 \mathrm{mim})$, they possess a varied length of side alkyl chain and methylation site. Via characterizing the strengthen of H-bond, ESP, NPA, AIM, and RDG analysis of isolated cation-Tyr and anion-Tyr systems, it can be found that the interaction between each cation-Tyr is stronger than that of $\mathrm{BF}_{4}-\mathrm{Tyr}$. And the methylation on the $\mathrm{N} 3$ site makes the strong $\mathrm{N}-\mathrm{H}$ H-bond donor change to weak $\mathrm{C}-\mathrm{H} \mathrm{H}$-bond donor, and $\mathrm{H}$-bond alters from $\mathrm{N} 3-\mathrm{H} \cdots \mathrm{O}_{\text {coo }}$ in $\mathrm{C}_{4}-2 \mathrm{mim}-\mathrm{Tyr}$ and $\mathrm{C}_{12}-2 \mathrm{mim}-\mathrm{Tyr}$ to $\mathrm{C} 2-\mathrm{H} \cdots$ Ocoo in $\mathrm{C}_{4}-3 \mathrm{mim}-\mathrm{Tyr}$ and $\mathrm{C}_{12}-3$ mim-Tyr. The methylation on the $\mathrm{C} 2$ site adjusts Tyr binding to strong N3-H
H-bond donor. Meanwhile, it further obtains from the energy decomposition analysis that electrostatic term mainly dominates the binding between all kinds of ion and Tyr, and the difference between the induction and dispersion terms in $\mathrm{C}_{4}-2 \mathrm{mim}$ - $\mathrm{Tyr}$ and $\mathrm{C}_{12}-2$ mim-Tyr is smaller than that in $\mathrm{C}_{4}-3$ mim-Tyr and $\mathrm{C}_{12}$ 3 mim-Tyr, confirming that extending side alkyl chain is less effective in reinforcement the binding because the methylation on the $\mathrm{C} 2$ site of cation hinders the benzene ring-alkyl chain interaction. Conversely, this difference is more apparent in $\mathrm{C}_{4}$ 3 mim-Tyr and $\mathrm{C}_{12}-3 \mathrm{mim}$-Tyr cases, which stems from the fact that the Tyr is oriented to the side alkyl chain when methylation on the $\mathrm{N} 3$ site, as a result, forming a weaker $\mathrm{C}-\mathrm{H} \mathrm{H}$-bond donor of the cation. Consequently, the binding of $\mathrm{C}_{4}-2 \mathrm{mim}$ and $\mathrm{C}_{12}$ 2 mim with Tyr is mainly induced by the H-bond, $\pi^{+}-\pi$ stacking interaction, and in $\mathrm{C}_{4}-3 \mathrm{mim}$ and $\mathrm{C}_{12}-3 \mathrm{mim}$ related cases, it is mainly governed by the $\mathrm{H}$-bond and $\mathrm{C}_{\text {Alkyl }}-\mathrm{H} \cdots \pi$ interaction, respectively. Whereas for $\mathrm{BF}_{4}-\mathrm{Tyr}$, the interaction is smaller than cation-Tyr systems, and the H-bond of $\mathrm{N}_{\mathrm{Tyr}}-\mathrm{H} \cdots \mathrm{F}$ is the governed item to the binding of $\mathrm{BF}_{4}$ and Tyr. The results of the complexes between ion pair and Tyr show that the change tendency of interaction energy of IL-Tyr systems is in line with that in cation-Tyr cases, and the ion pair further stabilizes the binding with Tyr. And the interaction strength and mechanism in cation-Tyr complexes can be adjusted by changing the methylation site and side alkyl chain length of the cation. Meanwhile, the anion further stabilizes the IL-Tyr complexes collaboratively. These findings potentially help to screen and design of biocompatible ILs in extracting and separating zwitterion amino acid in the future.

Supporting Information: available free of charge via the internet at http://www.whxb.pku.edu.cn.

Acknowledgment: Sincere thanks to Prof. Suojiang Zhang (IPE, CAS) for his guidance and help.

\section{References}

(1) Dong, K.; Liu, X. M.; Dong, H. F.; Zhang, X. P.; Zhang, S. J. Chem. Rev. 2017, 117, 6636. doi: 10.1021/acs.chemrev.6b00776

(2) Berthod, A.; Ruiz-Ángel, M. J.; Carda-Broch, S. J. Chromatogr. A 2018, 1559, 2. doi: 10.1016/j.chroma.2017.09.044

(3) Rogers, R. D.; Seddon, K. R. Science 2003, 302, 792. doi: $10.1126 /$ science. 1090313

(4) Wei, J.; Dong, H. X.; Chen, X.; Yang, Y. X.; Fang, D. W.; Guan, W.; Yang, J. Z. Acta Phys. -Chim. Sin. 2018, 34, 927. [魏杰, 董贺新, 陈 霞, 杨宇轩, 房大维, 关伟, 杨家振. 物理化学学报, 2018, 34, 927.] doi: 10.3866/PKU.WHXB201801112

(5) Caminiti, R.; Gontrani, L. The Structure of Ionic Liquids; Springer: Cham, Switzerland; 2013, pp. 127-148.

(6) Zhang, S. J.; Wang, J. J.; Lu, X. M.; Zhou, Q. Structures and Interactions of Ionic Liquids; Springer: Berlin, Germany; 2013, pp. 1-38. 
(7) Wang, B. S.; Qin, L.; Mu, T. C.; Xue, Z. M.; Gao, G. H. Chem. Rev. 2017, 117, 7113. doi: 10.1021/acs.chemrev.6b00594

(8) Chen, Y.; Mu, T. C. Green Energy Environ. 2019, 4, 95. doi: 10.1016/j.gee.2019.01.012

(9) Zhao, Q.; Chu, H. W.; Zhao, B. F.; Liang, Z.; Zhang, L. H.; Zhang, Y. K. Trac-Trend. Anal. Chem. 2018, 108, 239. doi: 10.1016/j.trac.2018.09.008

(10) Kumar, A.; Venkatesu, P. Biophys. Rev. 2018, 10, 841. doi: 10.1007/s12551-018-0411-x

(11) Tome, L. I.; Jorge, M.; Gomes, J. R.; Coutinho, J. A. J. Phys. Chem. B 2012, 116, 1831. doi: 10.1021/jp209625e

(12) Yang, H. P.; Chen, L.; Zhou, C. S.; Yu, X. J.; Yagoub, A. E. A.; Ma, H. L. Food Chem. 2018, 245, 346. doi: 10.1016/j.foodchem.2017.10.110

(13) Pei, Y. C.; Li, L.; Li, Z. Y.; Wu, C. Z.; Wang, J. J. Sep. Sci. Technol. 2012, 47, 277. doi: 10.1080/01496395.2011.609241

(14) Fang, F.; Zhao, Q.; Li, X.; Liang, Z.; Zhang, L. H.; Zhang, Y. Q. Anal. Chim. Acta 2016, 945, 39. doi: 10.1016/j.aca.2016.09.032

(15) Schröder, C. Top. Curr. Chem. 2017, 375, 25. doi: 10.1007/s41061-017-0110-2

(16) Kumar, A.; Bisht, M.; Venkatesu, P. Int. J. Biol. Macromol. 2017, 96, 611. doi: 10.1016/j.ijbiomac.2016.12.005

(17) Hunt, P. A. Top. Curr. Chem. 2017, 375, 59. doi: 10.1007/s41061-017-0142-7

(18) Scheiner, S.; Kar, T.; Gu, Y. J. Biol. Chem. 2001, 276, 9832. doi: 10.1074/jbc.M010770200

(19) Dong, K.; Zhang, S. J. Chem. -Eur. J. 2012, 18, 2748. doi: 10.1002/chem.201101645

(20) Kim, H. S.; Ha, S. H.; Sethaphong, L.; Koo, Y. M.; Yingling, Y. G. Phys. Chem. Chem. Phys. 2014, 16, 2944. doi: 10.1039/C3CP52516C

(21) Yan, H.; Wu, J. Y.; Dai, G. L.; Zhong, A. G.; Chen, H.; Yang, J. G.; Han, D. M. J. Lumin. 2012, 132, 622. doi: 10.1016/j.jlumin.2011.10.026

(22) Nandi, S.; Parui, S.; Halder, R.; Jana, B.; Bhattacharyya, K. Biophys. Rev. 2018, 10, 757. doi: 10.1007/s12551-017-0331-1

(23) Bai, S.; Chang, Y.; Liu, X. J.; Liu, F. F. Acta Phys. -Chim. Sin. 2014, 30, 1239. [白姝, 常顷, 刘小娟, 刘夫锋. 物理化学学报, 2014, 30, 1239.] doi: 10.3866/PKU.WHXB201405151

(24) Kumar, A.; Bisht, M.; Venkatesu, P. RSC Adv. 2016, 6, 18763. doi: $10.1039 / \mathrm{c} 5 \mathrm{ra} 26690 \mathrm{~d}$

(25) Klähn, M.; Lim, G. S.; Seduraman, A.; Wu, P. Phys. Chem. Chem. Phys. 2011, 13, 1649. doi: 10.1039/c0cp01509a

(26) Mendonca, C. M. N.; Balogh, D. T.; Barbosa, S. C.; Sintra, T. E.; Ventura, S. P. M.; Martins, L. F. G.; Morgado, P.; Filipe, E. J. M.; Coutinho, J. A. P.; Oliveira, O. N.; et al. Phys. Chem. Chem. Phys. 2018, 20, 29764. doi: 10.1039/c8cp05035j

(27) Frisch, M. J.; Trucks, G. W.; Schlegel, H. B.; Scuseria, G. E.; Robb,
M. A.; Cheeseman, J. R.; Scalmani, G.; Barone, V.; Mennucci, B.; Petersson, G. A.; et al. Gaussian 09, Revision D. 01; Gaussian Inc.; Wallingford, CT, USA, 2013.

(28) Gill, P. M. W.; Johnson, B. G.; Pople, J. A.; Frisch, M. Chem. Phys. Lett. 1992, 197, 499. doi: 10.1016/0009-2614(92)85807-M

(29) Zhao, Y.; Truhlar, D. G. Theor. Chem. Acc. 2008, 120, 215. doi: 10.1007/s00214-007-0310-x

(30) Grimme, S.; Antony, J.; Ehrlich, S.; Krieg, H. J. Chem. Phys. 2010, 132, 154104. doi: 10.1063/1.3382344

(31) Marenich, A. V.; Cramer, C. J.; Truhlar, D. G. J. Phys. Chem. B 2009, 113, 6378. doi: 10.1021/jp810292n

(32) Kessler, J.; Jakubek, M.; Dolenský, B.; Bouř, P. J. Comput. Chem. 2012, 33, 2310. doi: $10.1002 /$ jcc. 23063

(33) Jeziorski, B.; Moszynski, R.; Szalewicz, K. Chem. Rev. 1994, 94 , 1887. doi: 10.1021/cr00031a008

(34) Parrish, R. M.; Burns, L. A.; Smith, D. G. A.; Simmonett, A. C.; DePrince, A. E.; Hohenstein, E. G.; Bozkaya, U.; Sokolov, A. Y.; Di Remigio, R.; Richard, R. M.; et al. J. Chem. Theory Comput. 2017, 13, 3185. doi: 10.1021/acs.jctc.7b00174

(35) Saleh, G.; Gatti, C.; Presti, L. Comput. Theor. Chem. 2012, 998, 148. doi: 10.1016/j.comptc.2012.07.014

(36) Johnson, E. R.; Keinan, S.; Mori-Sánchez, P; Contreras-García, J.; Cohen, A. J.; Yang, W. T. J. Am. Chem. Soc. 2010, 132, 6498. doi: $10.1021 / \mathrm{ja} 100936 \mathrm{~W}$

(37) Lu, T.; Chen, F. W. J. Comput. Chem. 2012, 33, 580. doi: $10.1002 /$ jec. 22885

(38) Heßelmann, A.; Jansen, G. Phys. Chem. Chem. Phys. 2003, 5, 5010. doi: 10.1039/B310529F

(39) Hohenstein, E. G.; Sherrill, C. D. Wiley Interdiscip. Rev.: Comput. Mol. Sci. 2012, 2, 304. doi: 10.1002/wcms. 84

(40) Emamian, S.; Lu, T.; Kruse, H.; Emamian, H. J. Comput. Chem. 2019, 40, 2868. doi: 10.1002/jcc. 26068

(41) Cremer, D.; Kraka, E. Angew. Chem., Int. Ed. Engl. 1984, 23, 627. doi: 10.1002/anie.198406271

(42) Bader, R. F. W.; Beddall, P. M. J. Chem. Phys. 1972, 56, 3320. doi: $10.1063 / 1.1677699$

(43) Zhang, Y. Q.; He, H. Y.; Dong, K.; Fan, M. H.; Zhang, S. J. RSC $A d v$. 2017, 7, 12670. doi: 10.1039/c6ra27059j

(44) He, H. Y.; Zhang, S. J.; Liu, X. M.; Wang, J. Q.; Yao, X. Q.; Zhang, X. P. Fluid Phase Equilib. 2013, 360, 169. doi: 10.1016/j.fluid.2013.09.007

(45) Rao, S. S.; Gejji, S. P. J. Phys. Chem. A 2016, 120, 5665. doi: $10.1021 /$ acs.jpca.6b03985

(46) Matthews, R. P.; Welton, T.; Hunt, P. A. Phys. Chem. Chem. Phys. 2014, 16, 3238. doi: 10.1039/c3cp54672a

(47) Ju, Z. Y.; Yao, X. Q.; Luo, Z. F.; Cao, M. J.; Xiao, W. H. Carbohydr. Res. 2020, 487, 107882. doi: 10.1016/j.carres.2019.107882 